\title{
Policy research in accounting: A doctrinal research perspective
}

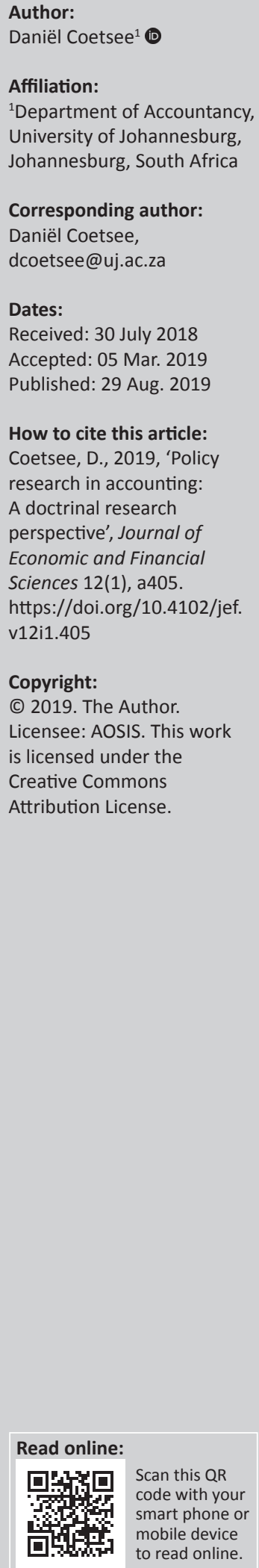

Orientation: The accounting literature acknowledged that a gap exists between accounting research and accounting practice and supported the argument that accounting research does not significantly contribute to accounting practice.

Research purpose: The purpose of this article is to evaluate the appropriateness of applying the research approaches identified in doctrinal research to the accounting policy debate.

Motivation for the study: The article is motivated by calls for accounting research, accounting standard-setters and accounting practice to work together to address the identified gap.

Research approach, design and method: The theoretical article interpreted the research approaches of doctrinal research for application in accounting research by following a structured approach of assessing each research approach separately.

Main findings: The article found that doctrinal research used logical argumentation of hermeneutics as foundation for the authoritative interpretation of practical documents. In applying aspects of hermeneutics, doctrinal research includes descriptive, interpretative, normative, critical and comparative research approaches, depending on the desired outcome of the research.

Practical/managerial implications: The article provides different research approaches that could be used by researchers to apply doctrinal research to assess the development of new policies in accounting.

Contribution/value-add: Hermeneutics and the different research approaches applied in doctrinal research add value by creating a research framework to conduct accounting policy research on accounting doctrines developed in practice. More methodological rigour is therefore created for accounting policy research and helps to bring practice and research closer to each other.

Keyword: accounting; accounting policy research; descriptive research; doctrinal research; hermeneutics; interpretative research; normative research; critical research; comparative research.

\section{Introduction and background}

Accounting researchers agree that a gap exists between accounting research and accounting practice, and that accounting research does not sufficiently contribute to accounting practice (Inanga \& Schneider 2005; Parker, Guthrie \& Linacre 2011; Singleton-Green 2009; Tucker \& Lowe 2014; Wilkinson \& Durden 2015). Calls have been made for accounting research, policy and practice to work together to bridge this gap (Evans, Burritt \& Guthrie 2011). The need to place a focus on the policy debate in accounting research is confirmed by the following quote from Guthrie and Parker (2016):

Academic researchers pay lip service to the need for their engagement with policy and practice, but for many, action in this regard simply does not happen. (p. 4)

It therefore becomes important for accounting researchers to consider the principles, rules and concepts of accounting as developed in practice. This may be better achieved by considering research approaches followed in other disciplines.

Doctrinal research, for example, is mainly applied in the disciplines of law, religion and ethics, as an approach to study the concepts, principles and rules (collectively referred to as doctrines in legal research) developed in practice (Hutchinson \& Duncan 2012; Mackor 2011). One specific discipline that extensively applies doctrinal research is law, which is also considered a professional 
discipline that creates norms that are applied in practice. Van Hoecke (2011) clarifies, referring to the legal discipline, that the empirical data used in doctrinal research are the legal text, that is, legislation and court decisions, while Siems (2011) states that doctrinal research criticises, explains, corrects and directs the doctrines developed in practice, and Husa (2011) refers to the interpretation and systematic validating of the doctrines. Doctrinal research is therefore, in essence, an academic debate regarding the nature and appropriateness of the doctrines developed in practice through current professional structures.

The remainder of the article firstly reflects on the nature of doctrinal research and then provides an overview of policy research in accounting. This is followed by a discussion of the different research approaches identified in the doctrinal research framework and their application to accounting policy research. These research approaches consist of the hermeneutic, descriptive, interpretative, normative, critical and comparative approaches. Finally, a conclusion is provided.

\section{Doctrinal research perspective Introduction}

Doctrinal research has a long historical perspective that was developed before the more contemporary scientific method became a research norm. Van Hoecke (2011) states that Roman legal doctrine was developed before Christ and that doctrinal approaches were even used in the Middle Ages by various authoritative structures to guide the practices of people. From an accounting perspective, the work of Luca Pacioli, in which he identified and explained the doubleentry approach as the basis of accounting (Sangster 2010), is a prime example of such historical doctrinal writings.

The focus of modern doctrinal research, however, has changed from guiding practice to the interpreting and evaluation of the principles, rules and concepts developed in practice (De Jong et al. 2011; Hutchinson \& Duncan 2012; Singhal \& Malik 2012). A possible reason for this change in doctrinal research is that professional practices, such as accounting and law, are developing doctrines applied in practice. It may therefore be argued that a key function of doctrinal research is to assess the appropriateness of the doctrines (concepts, principles and rules) developed in practice.

\section{Contextualising doctrinal accounting research}

Doctrinal research is often regarded as the most acceptable methodology in legal research (Hutchinson \& Duncan 2012). In support of this, Virgo (2011:222) declares that law is artificially constructed and therefore cannot be developed through the scientific method. The underlying doctrines are developed through both practice and academic debate (Chynoweth 2008; Hutchinson \& Duncan 2012). Watt (2011) agrees that the epistemological (how knowledge is created) function of doctrinal research is to interpret and order the source of law, which is the underlying doctrines captured in practice documents. Seen within this context, certain similarities exist between accounting and law that make doctrinal research an option in accounting policy research. Two views are provided regarding the similarities.

Firstly, Bell (2011) states that the evaluation of legal facts does not exist independently of legal categories and authority. Legal scholars, such as Hutchinson and Duncan (2012) and Chynoweth (2008), refer to a two-step approach for legal enquiries, in which the first step is to identify the facts and the second step is to identify the authority that should resolve the legal issue. Accounting practitioners clarifying accounting issues follow a similar process. Furthermore, in resolving any accounting issues, financial reporting standard-setters also determine the nature of any accounting issue under discussion, which they call the economic phenomena (International Accounting Standards Board [IASB] 2018), and then, by implication, use the conceptual framework for financial reporting as authority to develop financial reporting standards. The financial reporting standards issued then become the authority that practitioners should apply in practice for financial reporting purposes. Doctrinal research then plays a role in this regard by assessing the appropriateness of the developed authority.

Secondly, in the legal discipline, the applied framework to resolve practical issues is based on a bundle of rights and obligations (Bell 2011). Interestingly, the new conceptual framework for financial reporting of the IASB also refers to rights in the definition of an asset and to obligations in the definition of a liability (IASB 2018). Furthermore, International Financial Reporting Standards (IFRS) 15 Revenue from Contracts with Customers (IASB 2014) also uses the rights and obligations created in revenue contracts to assess the correct accounting or financial reporting treatment. Rights and obligations created in contracts between parties are therefore regarded as a cornerstone in establishing the appropriate accounting treatment, although substance over form also plays an important role in this assessment (IASB 2018).

It is important to note that doctrinal research differs from other academic research approaches in that it follows an insider approach (Kazmierski 2014). Bell (2011) explains that the objective of doctrinal research in law research is embedded in the institution, routines and procedures of the law as a discipline, and therefore cannot be studied from an outside perspective. This means that the people researching the doctrines could also be involved in developing and teaching the underlying doctrines.

\section{The nature of doctrinal research}

The incorporation of theory also differs in doctrinal research. Typically, research in any given discipline is based on theories developed in the discipline, or on related theories imported from other disciplines (Forgarty 2014; Inanga \& Schneider 2005). Doctrinal research, however, comes from another perspective. The concepts, principles and rules developed in practice are not regarded to be theory per se. As theory is the combining name for ultimate positions developed through 
the verification of the academic research processes (Deegan 2014; Gaffikin 2008), doctrines are the combining name for concepts, rules and principles developed in practice (Hutchinson \& Duncan 2012; McKerchar 2008). Doctrinal research, rather than theory, is therefore considered an alternative research approach to developed doctrines.

The question could be asked whether the doctrines developed could be regarded as theory. Van Hoecke (2011:17), in his discussion of doctrinal research, declares that '...the level of systematisation and concept building is the level of theory building...', and therefore implies that doctrinal research is also creating theory. Brownsword (2011), however, disagrees, stating that the purpose of theory is to create a critical vantage point to assess the appropriateness of standards and values. He further explains that law is, for instance, a moral enterprise that is deeply controversial and that there is a substantial difference between high theory and doctrinal detail. He also declares that doctrinal research is the first base of legal reasoning that clearly identifies and clarifies where practice is, and could consequently be regarded as a first step in evaluating the doctrines in practice before developed theory is incorporated.

According to Vranken (2011) and Westerman (2011), consistency and coherence of the practical system are maintained through doctrinal research. Westerman (2011) clarifies that the underlying legal principle is created through the (legal) system and that the purpose of doctrinal research is to maintain the appropriate application and authority of such a system. To achieve the maintenance of the system, she believes that doctrinal research orders and reconstructs legal matters and creates a historical perspective, with the purpose of creating both systematic integration and historical continuity. This perspective of doctrinal research is, however, not as broad as interdisciplinary research, because it still focuses on the internal system of developing authority for practice in a discipline.

In conclusion, therefore, doctrinal research is an approach that is directly linked to practice and evaluates the doctrines developed in practice. It differs from other research approaches in that it is conducted from an insider perspective and does not rely on theory developed through the academic process. Doctrinal research is a logical augmentation of the nature of, consistency of and gaps in doctrines developed in practice. The doctrines developed are used as authority to resolve practical issues and doctrinal research assesses the appropriateness of the authority.

\section{Overview of policy research in accounting}

Frequently published accounting research, such as the research of Barth (2014), Schmidt (2013), Penman (2007) and Walton (2006), comments, discusses, interprets or evaluates the doctrines of accounting developed in practice. A common feature of these policy-related articles is that the methodological approach followed is normally not discussed.
A lack of methodological rigour could therefore be an issue in policy research on the doctrines of accounting, which could, in turn, create research validity questions. Exceptions, however, exist in accounting policy research where the methodology of the researcher has been clarified, such as is explained below.

Van der Spuy (2015:811), in an article on the non-recognition of internally generated brands, declared that limited '....guidance for the composition of purely theoretical or conceptual accounting research papers...' is available. He uses a doctrinal research approach followed in legal research and clarifies that, like legal academics, accounting academics discuss issues or problems with the development of accounting standards and accounting frameworks. Van der Spuy (2015:812) identifies his methodology as following '...a qualitative, doctrinal approach through a purely theoretical and documentary analysis which is augmented and complemented with application of discussion and logical argumentation'. He also clarifies the doctrinal research approach followed by referring to the theoretical research methodology of Hutchinson and Duncan (2012), which comprises a systematic exposition of the rules developed in practice and the evaluation of the relationships between these rules. Therefore, some logical argumentation is being advanced about the authoritative guidance of doctrines developed in practice.

Baker and McGeachin (2013) discuss inconsistencies in IFRS regarding the accounting for liabilities, by following a theorybuilding process, and they identify (2013) their research method as follows:

...we have followed the approach to theory-building of Van de Ven (2007) who defines theory as 'a pattern of conceptual organisation that explains phenomena by rendering them intelligible'. The phenomena that we seek to explain are the conceptual inconsistencies in IFRS with respect to the recognition and measurement of liabilities. (p. 581)

Both these articles focus on explaining the effect of IFRSs and create validity for their research through the logic of their theoretical argumentation - even though the methodological grounding differs. Van der Spuy (2015) grounds his work in a doctrinal research perspective, while Baker and McGeachin (2013) focus on a theory-building process approach. The issue is, however, that the literature concludes that accounting does not have its own theory to base accounting research on and to inform practice (Forgarty 2014; Gaffikin 2008; Inanga \& Schneider 2005), and therefore the approach of Baker and McGeachin is not always possible in accounting policy research. In this regard, Forgarty (2014:1267) declares that any discipline is defined by its theory and therefore because of the lack of theory, the accounting discipline '....has never been on solid ground...' and '... is insecure about its footing on broader stages'. The lack of discipline-specific theory in the accounting discipline to base policy research on supports the argument to use doctrinal research approaches as alternatives.

A consequence of the lack of theory in accounting is that the underlying principles, rules and concepts of accounting are developed more through practice than research (Parker et al. 
2011; Singleton-Green 2009), which contributes to the perceived gap between accounting practice and research. Forgarty (2014:1268) specifically states that in accounting, '... practitioners have a less complex and less robust way of framing problems and finding solutions...', which is characterised by the absence of ' ... appropriate methodology and terminology...'. The focus in accounting practice is on a consultative process, and then specifically also on the due diligence process of the financial reporting standard-setters. The consultation process of practice does not rely on theory and this is where doctrinal research could make a contribution to assessing the doctrines developed in practice.

This discussion would be incomplete without mentioning the impact of social interpretative and critical research in accounting. Interpretative and critical research in accounting is applied to improve practice, but from a broader perspective (Armstrong 2008; Baker \& Bettner 1997; Hopwood 2007; Roslender \& Dillard 2003). The aim of social research in accounting is to evaluate accounting within its social, institutional and organisational context, to create broader interdisciplinary perspectives, to deal with complexities of practice and to create perspectives for change (Jeale \& Carter 2014; O’Dwyer \& Unerman 2014; Parker \& Guthrie 2014; Wilkinson \& Durden 2015). The benefit of the social research movement in accounting is that it clearly establishes accounting as an academic discipline that uses different research approaches and different methods of engagement. Accounting practice and policy, however, remain neglected (Parker 2012), and this is where the doctrinal methodology has a role to play. Although social interpretative and critical research is important in accounting research, such social research does not normally contribute to the doctrines of accounting.

The lack of methodological rigour in accounting policy research and the lack of specific accounting theory on which to base accounting research provide the rationale for the consideration of doctrinal research in accounting.

\section{Doctrinal research approaches Hermeneutical research approach}

Van Hoecke (2011) classifies doctrinal research as a hermeneutical approach, which entails the interpretation of text to identify meaning in text (Boland 1989; Gaffikin 2008; Prasad 2002). However, a broader view is that hermeneutics can also be used to interpret all aspects of social activities (Boland 1989). In Van Hoecke's (2011) view, the importance of the interpretation of text in a practical discipline should not be underestimated. Van Hoecke argues that the purpose of hermeneutics in doctrinal research is not to create a true or false outcome (as with the scientific method), but to create a convincing argument regarding the nature of existing doctrines. That is also in essence what accounting researchers are doing in theoretical accounting policy research as referred to above - even if they do not always discuss their methodological approaches.

Bell (2011) states that the authoritative paradigm is central to authoritative interpretation and explains that the objective of authoritative interpretation is to create an appropriate answer based on authoritative text within a system of enquiry. In this authoritative paradigm, Samuel's (2011) view is that hermeneutics is used intellectually to interpret text. Within an accounting context, the standard-setters are the authoritative source that creates the financial reporting standards, with the jurisdictional acceptance of the standards through regulation or legislation creating further legal backing for the financial reporting standards. The authority of the documents is validated through the structures that create them, and as such their authority is not questioned for practical application.

Samuel (2011) further clarifies that doctrinal research forms part of social sciences, in which human activity is assessed. In his view, the social facts captured in documents are complex, and therefore, the hermeneutical approach is relevant to interpret such documents. He also argues that intellectuality in doctrinal research hermeneutics is not only central from a methodological perspective, but also in the creation of knowledge. Hage (2011) concurs that doctrinal research contributes to knowledge by identifying what norms should be collectively enforced and declares that the justification of the doctrinal knowledge creation is achieved through sound arguments that are deductively valid.

Within the context of accounting, Boland (1989:592) considers hermeneutics as an alternative approach to read text, and in his view '...the hermeneutic problem is to gain meaning...' from text '... by engaging in an interpretative dialog...'. He believes that theories and organisational structures should be subjected to a process of systematic and critical reflection. His belief that accounting should be used as a text of human practices is emphasised by referring to Rorty (1979), who states that: 'A hermeneutic reading of accounting as text is the most hopeful way to approach an organisational understanding of accounting as a human practice'. One such practice could be to interpret the development of financial reporting and related accounting standards, and even the standards themselves. Because the standards are socially constructed, it is argued that the interpretation of the text is the starting point for evaluating these standards, and that it is important that accounting researchers become involved in this knowledge creation process.

Furthermore, from an accounting perspective, Gaffikin (2008:160) agrees that hermeneutics focuses on language, meaning and interpretation, that any new knowledge is based on historical knowledge, captured in documents, and that '...value-free inquiry is not possible and truth only exists as shared interpretations'. This is also the nature of doctrinal research, which focuses on historical documentation to create existing (new) knowledge.

For both Boland (1989) and Gaffikin (2008), the move to interpretation is a break with the objective view of the scientific method to a deeper and more fruitful understanding of accounting and establishes hermeneutics as part of the broader social science research movement. Hermeneutics is also seen as core to a doctrinal research approach. Within the 
hermeneutical framework, however, different approaches are possible, as discussed below.

\section{Descriptive research approach}

A descriptive approach to the research of documents aims to identify the social facts in the documents (Hage 2011). In legal doctrinal research, it would be to establish what the law in a specific circumstance is, while in accounting, it would be to identify what the accounting guidance envisioned by the financial reporting standard (or related documents) is.

Some doctrinal scholars (Van Hoecke 2011; Van Roermund 2011; Westerman 2011) attempt to create a link to positivistic research in that positive knowledge is created through the description of the specific information. This positive knowledge differs from typical positivistic knowledge in that it is not created through the scientific process. Rather, through the hermeneutic process of interpreting documents, the current knowledge of a discipline is, according to Bell (2011), described as creating an objective view of certain aspects of the discipline. Hage (2011) explains that in the legal discipline, the traditional hermeneutical approach is also used in doctrinal research to establish what he calls positive law and clarifies that such positive law creates legal certainty. Under the descriptive approach, hermeneutics is therefore used to identify current knowledge and does not contribute to what the knowledge should be.

Hage (2011) explains further that a social fact is established if significant people agree through some process of consensus. He therefore agrees that hermeneutics is used to establish the positive knowledge, and he concurs with Mackor (2011) that descriptive and other approaches (discussed hereafter) are interlinked and that most doctrinal research will go beyond mere description.

Within an accounting context, therefore, certainty is created firstly through the financial reporting standards issued by the standard-setters. Textbooks by practitioners and academics on financial reporting standards are used to create further certainty and positive accounting, through the financial reporting standards and textbooks. Therefore, a strong argument could be made that accounting researchers do not need to be involved in the process of creating such positive knowledge in the accounting discipline, and that social accounting researchers are correct to focus on broader aspects of the discipline. The discussion of the gap between accounting research and accounting practice, however, suggests the opposite. Doctrines are developed in accounting practice and accounting researchers should arguably become more involved in the policy debate to establish positive doctrines for accounting. For many accounting academics, this might not be appealing, but it is important to foster the accounting policy debate and reduce the gap between accounting research and accounting practice. Descriptive hermeneutic research may be the starting point to create positive accounting doctrines.

\section{Interpretative research approach}

Doctrinal reasoning is based on the art of interpretation (Samuel 2011), which aims to create an understanding of text under consideration. That is why the hermeneutic approach refers to authoritative interpretation. Interpretation is used in research to create a deeper understanding of a phenomenon (Armstrong 2008; Coetsee 2011; Henning, Van Rensburg \& Smit 2004), and therefore interpretation forms the basis of qualitative research. Doctrinal researchers agree that interpretation is applied in doctrinal research not only to create deeper meaning (Samuel 2011), but also to clarify internal consistency and coherence in documents (Bell 2011) and to understand the doctrines (Mackor 2011). Furthermore, interpretation could also be used to explain why a specific concept, principle or rule is valid within any given context (Van Hoecke 2011). Westerman (2011) goes further and argues that interpretation in doctrinal research is not primarily aimed at understanding and validation, but rather at ordering and clarification. This approach is especially applied in law to identify the doctrines in legislation and case law.

The question is whether validation (i.e. ordering and clarification) is really needed in accounting research, because the financial reporting standard-setters have taken over the development and interpretation function in accounting. The standard-setters do not only create the standards (the socalled positive knowledge), but also create separate interpretation committees to interpret divergence in the application of the financial reporting standards. The issue therefore becomes whether accounting academics should (or could) play a gatekeeper role in the positive accounting knowledge created in practice. This researcher argues in favour of this, because the (scholarly) function of interpretation could be used successfully to identify areas of uncertainty, inconsistencies and lack of coherence in the doctrines developed in practice, and to continually question the appropriateness of this positive knowledge.

\section{Normative research approach}

It is generally acknowledged that normative research considers questions around the pragmatic application of the doctrines in practice (Deegan 2014; Gaffikin 2008). In accounting research, normative research has lost its appeal because it is regarded as non-scientific (Godfrey et al. 2006; Mattessich 1992, 2002). Doctrinal researchers, Hutchinson and Duncan (2012), Chynoweth (2008) and McKerchar (2008), however, believe that it should play an important role in any practical discipline where doctrines are developed. In this regard, the purpose of doctrinal research is not only to describe and interpret the current doctrines, but also to direct changes in the doctrines (Hage 2011; Mackor 2011). Hage (2011) explains the underlying nature of normative research as follows:

\footnotetext{
...there is no principle difference between the justification of positions that are deemed 'factual' and positions that are deemed 'normative'. In both cases a person is absolutely justified in accepting such a position if the position fits in a coherent position set held by this person. (p. 38)
} 
Justification is therefore a core principle of doctrinal research, with the validity of doctrinal research being created through the appropriateness of the process applied (Chynoweth 2008; Kazmierski 2014; McKerchar 2008). Hage (2011), however, identifies problems in such an approach by stating that there are no true answer(s) or common ground for justification, and that the end result is a matter of personal choice.

Notwithstanding, Hage (2011:43) believes that the goal of normative research is to create a coherent set of positions through appropriate argumentation that contributes to knowledge. He therefore declares that the aim of doctrinal research is not only to create new positive knowledge, but also to question the current knowledge. Therefore, he believes that order is established by developing doctrines that are enforced collectively. Westerman (2011) agrees and states that in doctrinal research, normativity is created over time through both systematic integration and historical continuity with the aim not only to maintain and restore order, but also to create new order.

Mackor (2011) refers to the principle of imputation in normative research, which means that existing concepts, principles and rules are used to determine the norms applicable to other fact patterns. Therefore, imputed relationships, not causal relationships as in scientific research, are created to interpret fact patterns. These relationships are developed through the authoritative argumentation of doctrinal research. Mackor (2011) creates yet a further perspective on norms, implying that all doctrines can be classified into aspects of norms, as follows:

- Norm descriptions, which are normative statements (i.e. the positive norms or laws) of the current status of doctrines.

- Norm contentions, which aim to identify gaps and reduce any vagueness and ambiguity through authoritative interpretation.

- Norm recommendations, which aim to improve current norms.

Norm recommendations were the main aim of traditional normative research in accounting (Deegan 2014; Gaffikin 2008). The main difference in doctrinal research is that the researcher is taking an insider approach as part and parcel of the practical system (Kazmierski 2014; McKerchar 2008) and not an outsider approach that was the practice in traditional normative research in accounting to create validity for the research (Jeanjean \& Ramirez 2009).

In Mackor's (2011) view, all three types of norms follow the principle of imputation, making doctrinal research the main form of normative science that is applied in the disciplines of law, theology and ethics. Mackor (2011) states that, in these disciplines, an obligation is created for people to live from. This is not different from accounting, and the practice of accounting, through the standard-setting process, creates the financial reporting standards (i.e. the doctrines) that should be followed in practice. The problem in the accounting discipline is that the function of norm creation is primarily transferred to practice and the view of doctrinal researchers discussed above is that this function should not be left to practice alone. Accounting researchers cannot disregard these doctrines, and normative research is important to assess the appropriateness of these norms. In other practical disciplines, the doctrines developed are the first base of discipline-related research, and broader interdisciplinary research could also make use of the doctrines as a link to practice.

\section{Critical research approach}

The key purpose of critical research is to foster social change (Baker \& Bettner 1997; Richardson 2015; Roslender 2006). In pure critical research, a researcher needs to identify the perspective from which the critique is applied (Baker \& Bettner 1997; James 2008; Roslender 2006), and because normative research does not specifically require such a critical stance, it may be argued that it creates incompatible research approaches.

The observation from the doctrinal research literature is that pure critical research is not specifically addressed in doctrinal research. Two explanations could be given for this observation, namely that normative research is seen as a critical research approach used in doctrinal research to foster change; from there, its focus is more on the logic argumentation and doctrinal logic than the researcher's critical stance, and that critique is seen as integrated in the hermeneutic process of authoritative interpretation. This is the reason why Mackor (2011) refers to both norm contentions and norm recommendations.

The fact that critical research is often not considered as part of doctrinal research does not mean that pure critical research could not be conducted on the doctrines developed in practice. In this regard, Richardson (2015:77) declares that critical research could '...use any method that enhances the principle of critical theory'. Accounting researchers could, for example, consider different stances to assess the doctrines of accounting. Assessing the nature of the stances falls outside the scope of this article and could be addressed in future research. As an example, the process of Baker and McGeachin (2013), in their article discussed earlier, to include a process of theory building and the link to the accounting theory, is an attempt to make their research more critical. Further research could also assess whether the concepts developed in the IASB's Conceptual Framework for Financial Reporting (IASB 2018) could be used as a basis to evaluate the doctrines developed in a specific financial reporting standard.

Finally, hermeneutics also has a branch that is referred to as critical hermeneutics (Kinsella 2006; Roberge 2011). The argument is that in the qualitative interpretation of documents under a hermeneutic approach, uncertainty and ambiguity might arise. Critical hermeneutics is used to debate and resolve such ambiguity in qualitative research. 


\section{Comparative research approach}

Another approach that is followed in doctrinal research is comparative research (Adams 2011; Husa 2011; Samuel 2011), which compares doctrines developed in different jurisdictions. The concern in comparative research is that doctrines developed in other jurisdictions may be unfamiliar to the researcher and that the researcher needs to reconstruct the meaning of foreign doctrines (Adams 2011). Therefore, to make a comparison, the researcher needs to understand the other system that is compared. Understanding the interpretation and uses of different language is also important in comparative research (Husa 2011).

Comparative research might be less attractive in accounting research because of the establishment of the IASB and its drive to establish one internationally accepted set of financial reporting standards. Memoranda of understanding have also been established with the IASB's main competitor, the Financial Accounting Standards Board (FASB) in the United States of America, and other local standard-setters. Nevertheless, comparative studies could still be conducted in accounting research to identify differences between financial reporting standards of the IASB and the FASB and the accounting framework of other jurisdictions or countries that have not adopted IFRSs. Comparative research could also be used in accounting research to assess differences in public and private accounting frameworks and different tiers in accounting frameworks.

\section{Conclusion}

This article contributes to the accounting policy debate by reflecting on different research approaches within a doctrinal research methodology that could be pertinent in accounting policy research to evaluate the accounting doctrines developed in practice, that is, the concepts, principles and rules. Doctrinal research is typically applied in moral disciplines such as law, religion and ethics to assess the doctrines on which such practices are based. Doctrinal research creates a framework for policy research and differs from other academic research in that it is conducted from an insider's perspective and does not rely on theory developed through academic research. The validity of doctrinal research is created through the appropriateness of the argumentation.

An overview of policy research in accounting identifies an absence (or lack) of methodological rigour in policy research on the accounting doctrines. This article identified several issues in accounting policy research that provide opportunities for further debate and research, such as:

- Whether research could only be based on doctrines of accounting without any theoretical perspective.

- Whether, because of a lack of underlying theory in the accounting discipline, doctrinal research is a valid option.

- Whether a clear distinction exists between doctrines and theory in the academic literature.
The view expressed in this article is that doctrines of accounting are developed in practice and academics should not ignore these doctrines. Identifying and reflecting on the different research approaches used in doctrinal research can serve to clarify methodological issues and encourage more research on the doctrines of accounting. It was indicated that hermeneutics is the foundation of doctrinal research as the purpose of doctrinal research is to evaluate the practical documents in which the doctrines of a discipline are captured. Hermeneutics, in this regard, is seen as the interpretation of documents developed in practice to describe, interpret, evaluate and assess the doctrines. Descriptive, interpretative, normative, critical and comparative research approaches could therefore be used in the hermeneutic framework of doctrinal research, depending on the desired outcome of the research being undertaken.

Doctrines are normally developed through a process of consensus, and descriptive doctrinal research contributes to such consensus. Descriptive doctrinal research identifies positive doctrines applied in practice to create certainty, and as such doctrinal researchers consider descriptive hermeneutic research on the doctrines of a discipline as a substitute for the scientific method to create similar positive outcomes.

Interpretative doctrinal research, on the other hand, is used to create a deeper understanding of the doctrines developed and is used to identify gaps, inconsistencies and a lack of coherence in the doctrines. Authoritative interpretation of hermeneutics is the foundation for this approach.

Furthermore, normative doctrinal research questions the appropriateness of the doctrines developed in practice. Normative research in doctrinal research differs from pure critical research in that the stance of the researcher is not needed, and that the normative outcome is based on the logical argumentation of the researcher. Some doctrinal researchers are, however, of the view that all doctrinal research is normative in nature because the doctrines developed in practice are the norms that practice should apply, and therefore refers to norm descriptions, norm contentions and norm recommendations to distinguish between descriptive, interpretative and normative research.

Although doctrinal researchers normally do not refer to critical research, pure critical research could be conducted in doctrinal research if the researcher identifies a critical stance on which to base the evaluation of the developed doctrines. From an accounting research perspective, the issue is that the doctrines developed in practice are not regarded as academic theory, which makes a critical stance more difficult. However, accounting researchers could assess, in future research, whether the conceptual frameworks developed by standardsetters could be used as a basis to conduct critical research.

Finally, comparative doctrinal research could compare doctrines developed in different jurisdictions. Comparative research is difficult because the researcher needs to understand the economic, structural and cultural differences 
in different jurisdictions. The move of the IASB to develop a full set of IFRS makes the need for comparative research somewhat less attractive in accounting research. However, the interpretation and application of accounting doctrines applied in different jurisdictions means that some research opportunities may still exist.

Further research could build on the issues identified in this article, especially clarifying the difference between doctrines and theory in accounting research. Future research could also use the research approaches of doctrinal research identified in this article to classify accounting policy research. Integration of research approaches and lack of clear objectives in accounting policy research may, however, make such classification difficult.

\section{Acknowledgements}

This article is based on a chapter of a published thesis for the $\mathrm{PhD}$ (Accounting Science) degree at the Department of Accounting at North-West University, entitled 'Recovering a normative stance in accounting research by applying a legal doctrinal research methodology'. Sincere appreciation is expressed to Prof. Pieter Buys from the WorkWell Research Unit at the North-West University for his review of the article as part of the thesis.

\section{Competing interests}

The author declares that he has no financial or personal relationships that may have inappropriately influenced him in writing this article.

\section{Authors' contributions}

I declare that I am the sole author of this research article.

\section{Ethical considerations}

Ethical clearance was obtained for the PhD project completed at the North-West University. The ethical clearance number is EMS14/09/11-01.05.

\section{Funding}

This research received no specific grant from any funding agency in the public, commercial or not-for-profit sectors.

\section{Data availability statement}

Data sharing is not applicable to this article as now new data were created or analysed in this study.

\section{Disclaimer}

The views expressed in this article are the author's own and not an official position of the University of Johannesburg.

\section{References}

Adams, M., 2011, 'Doing what doesn't come naturally. On the distinctiveness of comparative law', in M. Van Hoecke (ed.), Methodologies of legal research: Which kind of method for what kind of discipline?, pp. 229-240, Hart Publishing, Oxford.
Armstrong, P., 2008, 'Calling out for more: Comment on the future of interpretive accounting research', Critical Perspectives on Accounting 19(6), 876-879. https:// doi.org/10.1016/j.cpa.2007.02.010

Baker, C.R. \& Bettner, M.S., 1997, 'Interpretive and critical research in accounting: A commentary on its absence from mainstream accounting research', Critical Perspectives on Accounting 8(4), 293-310. https://doi.org/10.1080/00014788. 2013.834811

Baker, R. \& McGeachin, A., 2013, 'Why is there inconsistencies in accounting for liabilities in IFRS? An analysis of recognition, measurement, estimation and conservatism', Accounting and Business Research 43(6), 579-604.

Barth, M.E., 2014, 'Measurement in financial reporting: The need for concepts', Accounting Horizon 28(2), 331-352. https://doi.org/10.2308/acch-50689

Bell, J., 2011, 'Legal research and the distinctiveness of corporate law', in M. Van Hoecke (ed.), Methodologies of legal research: Which kind of method for what kind of discipline?, pp. 155-176, Hart Publishing, Oxford.

Boland, R.J., 1989, 'Beyond the objectivist and subjectivist: Learning to read accounting as text', Accounting Organizations and Society 14(5/6), 591-604. https://doi.org/10.1016/0361-3682(89)90021-4

Brownsword, R., 2011, 'Maps, methodologies and critiques: Confessions of a contract lawyer', in M. Van Hoecke (ed.), Methodologies of legal research: Which kind of method for what kind of discipline?, pp. 133-154, Hart Publishing, Oxford.

Chynoweth, P., 2008, 'Legal research', in A. Knight \& L. Ruddock (eds.), Advance research methods in the built environment, pp. 28-38, Blackwell Publishing Ltd, West Sussex.

Coetsee, D., 2011, 'A comment on research frameworks applied in accounting research', South African Journal of Accounting Research 25(1), 81-102. https:// doi.org/10.1080/10291954.2011.11435154

Deegan, G.M., 2014, Financial accounting theory, McGraw-Hill Education (Australia), North Ryde, NSW.

De Jong, S.P.L., Van Arensbergen, P., Daemen, F. Van der Meulen, B. \& Van den Besselaar, P., 2011, 'Evaluation of research in context: An approach and two cases' Research Evaluation 20(1), 61-72. https://doi.org/10.3152/095820211X1294137 Research
1876346

Evans, E., Burritt, R. \& Guthrie, J. (eds.), 2011, Bridging the gap between academic accounting research and professional practice, The Institute of Chartered Accountants in Australia, Adelaide, South Australia and Centre for Accounting, Accountants in Australia, Adelaide, South Australia and Centre for Accountin
Governance and Sustainability, University of South Australia, Sydney, NSW.

Forgarty, T.J., 2014, 'A dream deferred: Interdisciplinary accounting in the US', Accounting, Auditing \& Accountability Journal 27(8), 1265-1270. https://doi. org/10.1108/AAAJ-08-2014-1800

Gaffikin, M.J.R., 2008, Accounting theory: Research, regulation and accounting practice, Pearson Education Australia, Frenchs Forest, NSW.

Godfrey, J., Hodgson, A., Holmes, S. \& Tarca, A., 2006, Accounting theory, Wiley, Milton, Queensland.

Guthrie, J. \& Parker, L.D., 2016, 'Whither the accounting profession, accountants and accounting researchers? Commentary and projections', Accounting, Auditing \& Accountability Journal 29(1), 2-10. https://doi.org/10.1108/AAAJ-10-2015-2263

Hage, J., 2011, 'The method of truly normative legal science', in M. Van Hoecke (ed.), Methodologies of legal research: Which kind of method for what kind of discipline?, pp. 19-44, Hart Publishing, Oxford.

Henning, E., Van Rensburg, W. \& Smit, B., 2004, Finding your way in qualitative research, Van Schaik Publishers, Pretoria.

Hopwood, A.G., 2007, 'Whither accounting research?', The Accounting Review 82(5), 1365-1374. https://doi.org/10.2308/accr.2007.82.5.1365

Husa, J., 2011, 'Comparative law, legal linguistics and methodology of legal doctrine', in M. Van Hoecke (ed.), Methodologies of legal research: Which kind of method for what kind of discipline?, pp. 209-228, Hart Publishing, Oxford.

Hutchinson, T.C. \& Duncan, N., 2012, 'Defining and describing what we do: Doctrinal legal research', Deakin Law Review 17(1), 83-119. https://doi.org/10.21153/ dlr2012vol17no1art70

Inanga, E.L. \& Schneider, W.B., 2005, 'The failure of accounting research to improve practice: A problem of theory and lack of communication', Critical Perspectives on Accounting 16(3), 227-248. https://doi.org/10.1016/S1045-2354(03)00073-X

International Accounting Standards Board (IASB), 2014, IFRS 15Revenue from contracts from customers, IASB, London.

International Accounting Standards Board (IASB), 2018, Conceptual framework for financial reporting, IASB, London.

James, K., 2008, 'A critical theory and postmodernist approach to teaching of accounting theory', Critical Perspectives on Accounting 19(5), 643-676. https:// doi.org/10.1016/j.cpa.2006.11.004

Jeale, I. \& Carter, C., 2014, 'Creative spaces in interdisciplinary research', Accounting, Auditing and Accountability Journal 27(8), 1233-1240. https://doi.org/10.1108/ AAAJ-06-2014-1735

Jeanjean, T. \& Ramirez, C., 2009, 'Back to the origins of positive theories: A contribution to an analysis of paradigm changes in accounting research', Accounting in Europe 6(1), 107-126. https://doi.org/10.1080/17449480902896510

Kazmierski, V., 2014, 'How much "Law" in legal studies? Approaches to teaching legal research and doctrinal analysis in a legal study program', Canadian Journal of Law and Society 29(3), 297-310. https://doi.org/10.1017/cls.2013.61

Kinsella, E.A., 2006, 'Hermeneutics and critical hermeneutics: Exploring possibilities within the art of interpretation', Forum: Qualitative Social Research 7(3), Art. 19. 
Mackor, A.R., 2011, 'Explanatory non-normative legal doctrine. Taking the distinction between theoretical and practical reasoning seriously', in M. Van Hoecke (ed.), Methodologies of legal research: Which kind of method for what kind of discipline?, pp. 45-70, Hart Publishing, Oxford.

Mattessich, R.V., 1992, 'On the history of normative accounting theory: Paradigm lost, paradigm retained?', Accounting, Business and Financial History 2(2), 181-198. haradigm retained?, Accounting, Business and $f$

Mattessich, R.V., 2002, 'Accounting schism or synthesis? A challenge for the conditional normative approach', Canadian Accounting Perspectives 1(2), 185-216. https:// doi.org/10.1506/PFG3-GHNH-YHKB-UPWN

McKerchar, M., 2008, 'Philosophical paradigms, inquiry strategies and knowledge claims: Applying the principles of research design and conduct to taxation', eJournal of Tax Research 6(1), 5-22.

O'Dwyer, B. \& Unerman, J., 2014, 'Realizing the potential of interdisciplinary in accounting research', Accounting, Auditing \& Accountability Journal 27(8), 1227-1232. https://doi.org/10.1108/AAAJ-07-2014-1756

Parker, L.D., 2012, 'Beyond the ticket and the brand: Imagining an accounting research future', Accounting and Finance 52(4), 1153-1182. https://doi.org/10.1111/ j.1467-629X.2012.00507.x

Parker, L.D. \& Guthrie, J., 2014, 'Assessing the directions of interdisciplinary accounting research', Accounting, Auditing and Accountability Journal 27(8), 1218-1226. https://doi.org/10.1108/AAAJ-06-2014-1737

Parker, L.D., Guthrie, J. \& Linacre, S., 2011, 'The relationship between academic accounting research and professional practice', Accounting, Auditing and Accountability Journal 24(1), 5-14. https://doi.org/10.1108/09513571111098036

Penman, S.H., 2007, 'Financial reporting quality: Is fair value a plus or a minus?', Accounting and Business Research 37(3), 33-44. https://doi.org/10.1080/000147 88.2007.9730083

Prasad, A., 2002, 'The contest over meaning: Hermeneutics as an interpretative methodology of understanding texts', Organizational Research Methods 5(1) 12-33. https://doi.org/10.1177/1094428102051003

Richardson, A.J., 2015, 'Quantitative research and the critical accounting project', Critical Perspectives on Accounting 32(Nov. 2015), 67-77. https://doi.org/10. 1016/j.cpa.2015.04.007

Roberge, J., 2011, 'What is critical hermeneutics?', Thesis 11 106(1), 5-22. https://doi. org/10.1177/0725513611411682

Roslender, R., 2006, 'Critical theory', in Z. Hoque (ed.), Methodology issues in accounting research: Theories and method, pp. 247-269, Spiramus, London.

Roslender, R. \& Dillard, J.F., 2003, 'Reflections on the interdisciplinary perspectives on accounting project', Critical Perspectives on Accounting 14(3), 325-351.

Rorty, R., 1979, Philosophy and the Mirror of Nature, Princeton University Press, Princeton, NJ.

Sangster, A., 2010, 'Using accounting history and Luca Pacioli to put relevance back into teaching of double entry accounting', Accounting Business \& Financial History 20(1), 23-39. https://doi.org/10.1080/09585200903504215
Samuel, G., 2011, 'Does one need an understanding of methodology in law before one can understand methodology in comparative law', in M. Van Hoecke (ed.), Methodologies of legal research: Which kind of method for what kind of discipline?, pp. 177-208, Hart Publishing, Oxford.

Schmidt, M., 2013, 'Equity and liabilities - A discussion of IAS 32 and a critique of the classification', Accounting in Europe 10(2), 201-222. https://doi.org/10.1080/174 49480.2013.834727

Siems, M.M., 2011, 'A world without law professors', in M. Van Hoecke (ed.), Methodologies of legal research: Which kind of method for what kind of discipline?, pp. 71-86, Hart Publishing, Oxford.

Singleton-Green, B., 2009, 'The communication gap: Why doesn't accounting research make a greater contribution to debates on accounting policy?', Accounting in Europe 7(2), 129-145. https://doi.org/10.1080/17449480.2010.511880

Singhal, A.K. \& Malik, I., 2012, 'Doctrinal and socio-legal methods of research: Merits and demerits', Educational Research Journal 2(7), 252-256.

Tucker, B.P. \& Lowe, A.D., 2014, 'Practitioners are from Mars, academics are from Venus? An investigation of the research-practice gap in management accounting', Accounting, Auditing \& Accountability Journal 27(3), 394-425. https://doi. org/10.1108/AAAJ-01-2012-00932

Van der Spuy, P.V.A., 2015, 'Non-recognition of internally generated brands: Implications for the usefulness of financial statements', Journal of Economic and Implications for the usefulness of financial statements', Journal of Econc
Financial Science 8(3), 808-822. https://doi.org/10.4102/jef.v8i3.123

Van Hoecke, M., 2011, 'Legal doctrine: Which method(s) for what kind of discipline?', in M. Van Hoecke (ed.), Methodologies of legal research: Which kind of method for what kind of discipline?, pp. 1-18, Hart Publishing, Oxford.

Van Roermund, B., 2011, 'Theory and object in law: The case for legal scholarship as indirect speech', in M. Van Hoecke (ed.), Methodologies of legal research: Which kind of method for what kind of discipline?, pp. 277-286, Hart Publishing, Oxford.

Virgo, G., 2011, 'Why study Law? The relevance of legal information to the law student, researcher and practitioner', Legal Information Management 11(04) 221-226. https://doi.org/10.1017/S1472669611000788

Vranken, J., 2011, 'Methodology of legal doctrinal research. A comment on Westermam', in M. Van Hoecke (ed.), Methodologies of legal research: Which kind of method for what kind of discipline?, pp. 111-122, Hart Publishing, Oxford.

Walton, P., 2006, 'A research note: Fair value and executory contacts: Moving the boundaries in international financial reporting', Accounting and Business Research 36(4), 337-343. https://doi.org/10.1080/00014788.2006.9730031

Watt, H.M., 2011, 'The epistemological function of "la Doctrine"', in M. Van Hoecke (ed.), Methodologies of legal research: Which kind of method for what kind of discipline?, pp. 123-132, Hart Publishing, Oxford.

Westerman, P.C., 2011, 'Open or autonomous? The debate of legal methodology as a reflection of the debate of law', in M. Van Hoecke (ed.), Methodologies of legal research: Which kind of method for what kind of discipline?, pp. 87-110, Hart Publishing, Oxford.

Wilkinson, B.R. \& Durden, C.H., 2015, 'Inducing structural change in academic accounting research', Critical Perspectives on Accounting 26, 23-36. https://doi. org/10.1016/j.cpa.2014.03.002 